\title{
Studi Akumulasi Pigmen $\beta$-Cryptoxanthin untuk Membentuk Warna Jingga Buah Jeruk di Daerah Tropika
}

\author{
Study on the Accumulation of B-Cryptoxanthin Pigment to Induce Orange Color on \\ Citrus Fruits in the Tropic
}

Inanpi Hidayati Sumiasih ${ }^{1,3 *}$, Taruna Shafa Arzam ${ }^{1}$, Roedhy Poerwanto ${ }^{2}$, Darda Efendi $^{2,4}$, Andria Agusta $^{5}$, dan Sri Yuliani ${ }^{6}$

Diterima 25 Oktober 2017/Disetujui 14 Maret 2018

\begin{abstract}
Degreening is a transformation process on peel which enables it to change color from green to orange on citrus fruits. The orange color of the peel comes from the mixture of carotenoid pigments, such as $\beta$-cryptoxanthin and $\beta$-citraurin. The pigments contributed in the formation of $\beta$-citraurin are $\beta$-cryptoxanthin and zeaxanthin. The objectives of this study were (1) to obtain proper degreening temperature in the orange color formation of several citrus varieties, and (2) to identify and determine pigments of $\beta$-cryptoxanthin pigment and total chlorophyll content in citrus peel after degreening. This study was conducted at PKHT IPB and LIPI Cibinong from July 2013 to December 2013, and from February 2016 to May 2017. About 100 ppm of ethylene gas was injected into a citrus-containing box using $5 \mathrm{ml}$ syringe, then the box was placed in cool storage at $15^{\circ} \mathrm{C}, 20^{\circ} \mathrm{C}$ and room temperature, for 72 hours. The results showed that the best colors of Keprok Selayar and Keprok Tejakula were obtained by the degreening at $15^{\circ} \mathrm{C}$, in Siam Kintamani it was obtained by degreening at $20^{\circ} \mathrm{C}$. Degreening significantly reduced the total chlorophyll content, and increased $\beta$-cryptoxanthin content. The content of $\beta$-cryptoxanthin after degreening was 3 folds higher on highland Citrus reticulata than lowland citrus.
\end{abstract}

Keywords: citrus color index, chlorophill, degreening, ethylene, tropical citrus

\section{ABSTRAK}

Degreening adalah proses perombakan warna hijau pada kulit jeruk diikuti dengan proses pembentukan warna jingga. Warna jingga adalah campuran antara $\beta$-cryptoxanthin dengan $\beta$ citraurin. Pigmen yang berkontribusi dalam pembentukan $\beta$-citraurin adalah $\beta$-cryptoxanthin dan zeaxanthin. Tujuan penelitian ini ialah (1) Mendapatkan suhu degreening yang tepat dalam pembentukan warna jingga pada beberapa varietas jeruk, (2) Identifikasi dan penentuan kadar pigmen $\beta$-cryptoxanthin dan kandungan total klorofil pada kulit jeruk setelah degreening. Penelitian ini dilakukan di PKHT IPB dan LIPI Cibinong pada bulan Juli 2013 sampai Desember 2013, dan bulan Februari 2016 sampai Mei 2017. Degreening dilakukan dengan menginjeksikan gas etilen konsentrasi $100 \mathrm{ppm}$ ke dalam wadah tertutup yang berisi jeruk menggunakan syringe $5 \mathrm{ml}$, kemudian disimpan pada suhu $15{ }^{\circ} \mathrm{C}, 20{ }^{\circ} \mathrm{C}$ dan suhu ruang, selama $72 \mathrm{jam}$. Hasil penelitian menunjukkan bahwa warna terbaik jeruk Keprok Selayar dan Tejakula diperoleh dengan degreening pada suhu $15{ }^{\circ} \mathrm{C}$, Siam Kintamani diperoleh dengan degreening pada suhu $20^{\circ} \mathrm{C}$. Degreening dapat menurunkan kandungan total klorofil secara tajam, dan terbukti meningkatkan kandungan pigmen $\beta$-cryptoxanthin. Kandungan pigmen $\beta$-cryptoxanthin setelah degreening 3 kali lebih tinggi pada jeruk keprok dataran tinggi dibandingkan dengan dataran rendah.

Kata kunci: citrus color index, degreening, etilen, jeruk tropika, klorofil

\footnotetext{
${ }^{1}$ Mahasiswa Program Studi Agronomi dan Hortikultura, Sekolah Pascasarjana, Institut Pertanian Bogor J1. Meranti Kampus IPB Dramaga, Bogor 16680 dan

${ }^{2}$ Departemen Agronomi dan Hortikultura, Institut Pertanian Bogor, Jl. Meranti Kampus IPB Dramaga, Bogor 16680

${ }^{3}$ Universitas Trilogi, d/h STEKPI Jl. TMP Kalibata No. 1, Jakarta 12760

${ }^{4}$ Pusat Kajian Hortikultura Tropika, Institut Pertanian Bogor, Jl. Raya Pajajaran, Kampus IPB Baranangsiang, Bogor 16144

${ }_{5}^{5}$ Lembaga Ilmu Pengetahuan Indonesia (LIPI), Cibinong Science Center, Jl. Raya Jakarta-Bogor Km.46 Cibinong - Bogor 16911

${ }^{6}$ Balai Besar Penelitian dan Pengembangan Pascapanen Pertanian (BBP)

Jl. Tentara Pelajar No. 12 Kampus Penelitian Pertanian Cimanggu Bogor 1611

E-mail: inanpihs@trilogi.ac.id (*Penulis korespondensi)
} 


\section{PENDAHULUAN}

Jeruk merupakan produk hortikultura yang mempunyai potensi pengembangan yang besar di Indonesia. Buah jeruk mengandung karotenoid yang paling kompleks karena kaya akan pigmen seperti lycopene, $\beta$-cryptoxanthin, $\beta$-citraurin, dan zeaxanthin. Jeruk juga mengandung potassium, bioflavonoid, asam folat, vitamin $\mathrm{C}$ dan fitonutrient lain yang bermanfaat untuk kesehatan manusia (Kato et al., 2006).

Permintaan buah jeruk semakin meningkat, seiring dengan meningkatnya kesadaran masyarakat terhadap nilai gizi. Peningkatan ini menyebabkan Indonesia mengimpor jeruk segar dalam jumlah yang besar. Peningkatan permintaan konsumen buah jeruk impor diantaranya disebabkan karena ketertarikan konsumen terhadap penampilan dan cita rasa buah jeruk yang berwarna jingga. Di sisi lain, ketersediaan jeruk keprok Indonesia yang berwarna kuning-jingga sedikit dan tidak kontinyu, ikut menyebabkan tingginya impor buah jeruk (Arzam et al., 2015). Berdasarkan Deptan (2015), Indonesia mengimpor jeruk sebesar 24937 ton di tahun 2010 dan melonjak mencapai 147255 ton pada tahun 2014.

Penelitian Shanti (2007) dan Nafisah (2013) menunjukkan bahwa sebanyak 85 persen responden di Bogor memilih untuk membeli jeruk impor, sedangkan 15 persen responden memilih untuk membeli jeruk lokal. Hal tersebut disebabkan penampilan buah jeruk lokal kurang menarik dibandingkan dengan buah jeruk impor. Jeruk lokal indonesia perlu dikembangkan untuk meningkatkan kualitas warna buah jeruk menjadi lebih menarik.

Peningkatan kuantitas dan kualitas buah jeruk perlu dilakukan guna memenuhi permintaan pasar. Salah satu cara untuk memenuhi permintaan konsumen sesuai selera yaitu dengan pembentukan warna jingga pada buah jeruk, sehingga perlu dilakukan perlakuan degreening dengan etilen segera setelah panen. Etilen terbukti berperan dalam mengurangi kandungan klorofil dalam kulit buah hingga menyebabkan terjadinya perubahan warna pada kulit jeruk dari hijau ke jingga. Perlakuan pemberian etilen pada pascapanen buah jeruk merupakan perlakuan degreening untuk menurunkan kandungan klorofil pada kulit buah (Karthik et al., 2010). Durasi pemaparan etilen yang dianjurkan untuk menghindari munculnya perubahan internal buah adalah tidak melebihi 72-96 jam (Martinez-Javega et al., 2008)

Degreening adalah proses perombakan warna hijau pada kulit jeruk diikuti dengan proses pembentukan warna jingga. Degreening yang dilakukan di Indonesia selama ini tidak berhasil membentuk warna jingga, tetapi kuning. Jeruk berwarna kuning tidak disukai konsumen karena dianggap sudah hampir busuk. Warna kuning pada kulit jeruk terbentuk oleh $\beta$-cryptoxanthin (Kato et al., 2006; Fanciullino et al., 2008; Zhou et al., 2010), warna jingga adalah campuran antara $\beta$ cryptoxanthin dengan $\beta$-citraurin pada karotenoid, sedangkan pigmen yang berkontribusi dalam pembentukan $\beta$-citraurin adalah $\beta$-cryptoxanthin dan zeaxanthin (Ma et al., 2013; Rodrigo et al., 2013).

Penelitian tentang pembentukan pigmen pada kulit jeruk di Indonesia belum pernah dilakukan. Namun berdasarkan literatur di atas, kegagalan degreening di daerah tropika membentuk warna jingga karena $\beta$-citraurin hanya terbentuk pada suhu rendah. Oleh karena itu dikembangkan teknologi degreening yang mampu menjadikan jeruk tropika berwarna jingga, dan mengidentifikasi $\beta$-cryptoxanthin pada karotenoid sebagai pembentuk warna jingga. Tujuan penelitian ini ialah (1) Mendapatkan suhu degreening yang tepat dalam pembentukan warna jingga pada beberapa varietas jeruk dengan elevasi lahan yang berbeda, dan (2) Identifikasi pigmen $\beta$ cryptoxanthin dan kandungan total klorofil pada kulit jeruk setelah degreening.

\section{BAHAN DAN METODE}

Penelitian ini dilakukan di PKHT IPB dan Pusat Penelitian Biologi-LIPI Cibinong. Penelitian berlangsung pada bulan Juli 2013 sampai Desember 2013, dan pada bulan Februari 2016 sampai Mei 2017.

Rancangan percobaan yang digunakan ialah Rancangan Acak Kelompok Faktorial. Perlakuan terdiri atas 2 faktor yaitu varietas jeruk dan suhu degreening. Faktor varietas jeruk terdiri atas Keprok Selayar, Keprok Tejakula, dan Siam Kintamani. Faktor suhu terdiri atas $15^{\circ} \mathrm{C}, 20^{\circ} \mathrm{C}$ dan suhu ruang $\left( \pm 30^{\circ} \mathrm{C}\right)$. Total kombinasi perlakuan adalah 9 dan diulang tiga kali, sehingga terdapat 27 satuan percobaan. 
Bahan yang digunakan ialah jeruk dataran rendah pada ketinggian 50 meter di atas permukaan laut ( $\mathrm{m} \mathrm{dpl}$ ) (Keprok Tejakula) yang dipanen dari Kabupaten Singaraja dan jeruk dataran tinggi pada ketinggian $\pm 1200 \mathrm{~m} \mathrm{dpl}$ (Keprok Selayar dan Siem Kintamani) yang dari Kabupaten Bangli, gas etilen konsentrasi 100 ppm, suhu $15^{\circ} \mathrm{C}, 20{ }^{\circ} \mathrm{C}$ dan $\pm 30^{\circ} \mathrm{C}$.

Peubah yang diamati antara lain: Padatan terlarut total (PTT). Jus buah dari buah sampel diambil dari setiap perlakuan dan diukur PTT dengan menggunakan hand refraktometer. Pengukuran dilakukan dengan cara memberikan setetes cairan buah pada lensa pembaca hand refraktometer. Setiap melakukan pengukuran, lensanya dibersihkan dahulu dengan akuades dan tisu. Angka yang muncul pada layar merupakan PTT dalam buah jeruk.

Total Asam Tertitrasi. Kandungan asam diukur dengan menghitung persen asam tertitrasi. Jus buah ditimbang sebanyak $25 \mathrm{~g}$ dimasukkan ke dalam labu ukur serta ditambahkan aquades hingga $100 \mathrm{ml}$, kemudian dimasukkan ke dalam erlenmeyer sebanyak 25 $\mathrm{ml}$ untuk dua kali ulangan. Setelah itu, filtrat disaring menggunakan saringan glasswol. Filtrat buah sebanyak $25 \mathrm{ml}$ dititrasi dengan metode titrasi basa dengan $\mathrm{NaOH} 0,1 \mathrm{~N}$ dan indikator phenolptialin (tiga tetes). Titrasi dilakukan sampai filtrat berwarna merah muda stabil. Kandungan asam tertitrasi dihitung menggunakan rumus:

$$
\text { Asam }\left(\frac{\mathrm{mg}}{100 \text { gram }}\right)=\frac{(\mathrm{mL} \mathrm{NaOH} \times \mathrm{N} \mathrm{NaOH} \times \mathrm{fp} \times 64)}{\text { bobot bahan }(\mathrm{mg})} \times 100 \%
$$

Keterangan: $\mathrm{ml} \mathrm{NaOH}=$ Volume $\mathrm{NaOH}$ yang terpakai pada titrasi; $\mathrm{N} \mathrm{NaOH}=$ Volume $\mathrm{NaOH}$ yang terpakai pada titrasi; $\mathrm{Fp}=$ faktor pengencer $(100 / 25) ; 64=$ faktor asam dominan; $\mathrm{mg}$ sampel $=25.000 \mathrm{mg}$.

Nilai hue dan Citrus Color Indeks (CCI). Perubahan kualitas warna kulit buah jeruk diukur dengan Minolta Color Reader tipe 310. Alat ini mempunyai sistem notasi warna hunter (sistem warna L, a, dan b). Hasil pengukuran dinyatakan dalam Citrus Color Index (CCI) dan derajat hue. Sistem notasi warna Hunter dicirikan dengan 3 parameter warna, yaitu notasi L menyatakan parameter kecerahan (lightness), notasi a menyatakan warna kromatik campuran merah-hijau, sedangkan notasi $b$ menyatakan warna kromatik campuran biru-kuning (Andarwulan et al., 2011). Hasil pengukuran nilai a dan $\mathrm{b}$ dikonversikan ke dalam satuan kromatik derajat hue $\left({ }^{\circ} h u e\right)$. Nilai ${ }^{\circ}$ hue mendeskripsikan warna murni yang menunjukkan warna dominan dalam campuran beberapa warna. Berdasarkan Manera et al. (2012), nilai ${ }^{\circ}$ hue digunakan persamaan sebagai berikut: ${ }^{\circ}$ hue $=\tan ^{-1}\left(\frac{\mathrm{b}}{\mathrm{a}}\right)$

Nilai Citrus Color Indeks (CCI) merupakan formula yang banyak dipergunakan untuk melihat kualitas warna kulit buah jeruk.
Menurut Jimenez-Cueata et al. (1981) bahwa nilai CCI digunakan persamaan sebagai berikut: $\mathrm{CCI}=\frac{1000 . \mathrm{a}}{\mathrm{L} \cdot \mathrm{b}}$. Indeks warna jeruk (CCI) digunakan kisaran sebagai berikut: $\mathrm{CCI}<=-5$ (hijau gelap), $-5<\mathrm{CCI}<=0$ (hijau), $0<\mathrm{CCI}<=3$ (hijau kekuningan), $3<\mathrm{CCI}<=6$ (kuning kehijauan), $6<\mathrm{CCI}<=8 \quad$ (jingga kekuningan), $\quad 8<\mathrm{CCI}<=10 \quad$ (jingga), dan CCI $>10$ (jingga gelap).

Kandungan total klorofil diukur menggunakan metode spektrofotometri. Kulit jeruk ditimbang sebesar 0.5 gram untuk digerus dan diekstraksi dengan acetris sebanyak $2 \mathrm{~mL}$, kemudian dimasukkan ke microtube dan disentrifuge selama 10 detik. Filtrat hasil sentrifuge dimasukkan dalam tabung reaksi sebanyak $1 \mathrm{~mL}$, ditambahkan $3 \mathrm{~mL}$ acetris, lalu ditempatkan dalam cuvet untuk diukur menggunakan alat spektrofotometer pada panjang gelombang 537, 647, dan $663 \mathrm{~nm}$. Menurut Sims dan Gamon (2002), setelah memperoleh nilai absorbansi, kandungan total klorofil dapat dihitung dengan rumus:

$$
\begin{aligned}
& \operatorname{Chl}_{\boldsymbol{a}}=0.01373^{*} A_{663}-0.000897^{*} A_{537}-0.003046^{*} A_{647}
\end{aligned}
$$

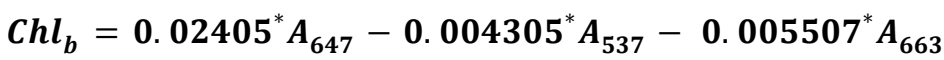

$$
\begin{aligned}
& \text { Total Klorofil }=C h l_{a}+C h l_{b}
\end{aligned}
$$






Gambar 1. Gambar kurva standar pigmen $\beta$-cryptoxanthin

Ekstraksi karotenoid dilakukan dengan memisahkan kulit buah jeruk dari bagian daging buah jeruk, kemudian didinginkan dengan cairan nitrogen di dalam tabung dewar sampai digunakan. Identifikasi karotenoid dilakukan dengan metode yang dijelaskan oleh Kato et al. (2004). Pigmen diekstrak dari sampel dengan larutan heksana; aseton: ethanol $(2: 1: 1, \mathrm{v} / \mathrm{v})$ yang mengandung $0.1 \%(\mathrm{w} / \mathrm{v}) 2.6$ di tert butyl 4 methylphenol dan $10 \%$ (w/v) magnesium karbonat. Setelah pelarut organik menguap secara keseluruhan, ekstrak yang mengandung karotenoid yang diesterifikasi ke asam lemak, disaforifikasi dengan $20 \%$ (w/v) methanolic $\mathrm{KOH}$. Ekstrak yang larut dalam air dihilangkan dengan $\mathrm{NaCl}$ jenuh. Pigmen dipartisi pada fase dhietyl ether dan diuapkan menjadi kering.

Analisis $\beta$-cryptoxanthin dan zeaxanthin diukur dengan melarutkan kembali residu karotenoid ke dalam larutan methyl tert butyl ether: methanol $(4: 6, \mathrm{v} / \mathrm{v})$. Sebuah aliquot (30 $\mu \mathrm{L})$ dipisahkan dengan system fase terbalik HPLC, pada tingkat aliran $1 \mathrm{~mL} \mathrm{~min}^{-1}$. Standar dari $\beta$-cryptoxanthin disiapkan berdasarkan metode yang dideskripsikan dengan berat segar (fresh weight) mikrogram per gram (menyiapkan kalibrasi dari standar). Kuantifikasi $\beta$-cryptoxanthin, zeaxanthin dan $\beta$-carotene dilakukan dalam 3 ulangan. Standar pigmen (Gambar 1), dan persamaan linear $\mathrm{y}=$ $41433 x+101291, R^{2}=0.9997$.

Data hasil pengamatan diuji dengan sidik ragam pada taraf $\alpha=5 \%$ menggunakan program SAS (Statistical Analysis System), yang diuji lanjut dengan Duncan Multiple Range Test (DMRT) pada taraf $\alpha=5 \%$.

\section{HASIL DAN PEMBAHASAN}

\section{Pengaruh Suhu Degreening terhadap Beberapa Varietas Jeruk pada Nilai Citrus Color Indeks (CCI)}

Peningkatan nilai CCI menunjukkan bahwa terjadi perubahan warna dari hijau menjadi jingga. Suhu degreening berpengaruh terhadap nilai CCI pada jeruk Keprok Selayar, Keprok Tejakula dan Siam Kintamani ditunjukkan pada Tabel 1. Hasil pengukuran nilai CCI jeruk Keprok Selayar yang diberikan perlakuan degreening pada suhu $15^{\circ} \mathrm{C}$ dan 20 ${ }^{0} \mathrm{C}$ masing-masing sebesar CCI sebesar 7.44 dan 6.18 pada hari ke-4. Hal tersebut memperlihatkan bahwa jeruk Keprok Selayar telah berubah warna menjadi jingga kekuningan, dan berubah menjadi jingga cerah hari ke-8 dengan nilai 8.31 pada suhu degreening $15{ }^{\circ} \mathrm{C}$. Degreening pada suhu ruang memperlihatkan pembusukan sejak hari ke-4 (Gambar 2).

Nilai CCI pada jeruk Keprok Tejakula dengan degreening pada suhu $15{ }^{\circ} \mathrm{C}$ dan $20{ }^{\circ} \mathrm{C}$ masing-masing membentuk warna jingga kekuningan pada hari ke-12, dan suhu ruang pada hari ke-8. Tingkat pembusukan buah menjadi tinggi dengan degreening suhu $20{ }^{\circ} \mathrm{C}$ dan ruang.

Degreening dengan suhu $20{ }^{\circ} \mathrm{C}$ pada Siam Kintamani menunjukkan perubahan warna kulit menjadi jingga kekuningan pada hari ke-12 dengan nilai CCI 6.90. Degreening pada suhu $30^{\circ} \mathrm{C}$ menunjukkan warna kulit yang kecoklatan dan membusuk. 
Tabel 1. Perubahan nilai Citrus Color Index (CCI) berbagai jenis jeruk pada beberapa suhu degreening

\begin{tabular}{|c|c|c|c|c|c|c|}
\hline \multirow[t]{2}{*}{ Jenis Jeruk } & \multirow[t]{2}{*}{ Suhu } & \multirow{2}{*}{$\begin{array}{l}\text { Panen } \\
0 \text { HSP }\end{array}$} & \multicolumn{4}{|c|}{$\begin{array}{l}\text { Nilai CCI pada hari setelah perlakuan } \\
\text { (HSP) ke- }\end{array}$} \\
\hline & & & 1 & 4 & 8 & 12 \\
\hline \multirow{3}{*}{$\begin{array}{l}\text { Keprok } \\
\text { Selayar }\end{array}$} & Suhu $15^{\circ} \mathrm{C}$ & 2.14 & 5.33 & $7.44 \mathrm{a}$ & $8.31 \mathrm{a}$ & $9.24 \mathrm{a}$ \\
\hline & Suhu $20{ }^{\circ} \mathrm{C}$ & 2.00 & 4.23 & $6.18 \mathrm{ab}$ & $6.98 \mathrm{~b}$ & $8.88 \mathrm{a}$ \\
\hline & Suhu Ruang $\left( \pm 30^{\circ} \mathrm{C}\right)$ & 2.57 & 4.37 & - & - & - \\
\hline \multirow{3}{*}{$\begin{array}{l}\text { Keprok } \\
\text { Tejakula }\end{array}$} & Suhu $15^{\circ} \mathrm{C}$ & -0.72 & 2.20 & $4.22 \mathrm{~b}$ & $5.73 \mathrm{~b}$ & $6.57 \mathrm{~b}$ \\
\hline & Suhu $20{ }^{\circ} \mathrm{C}$ & 0.12 & 2.57 & $5.03 \mathrm{~b}$ & $5.79 \mathrm{~b}$ & $6.22 \mathrm{~b}$ \\
\hline & Suhu Ruang $\left( \pm 30^{\circ} \mathrm{C}\right)$ & -0.77 & 3.22 & $5.00 \mathrm{~b}$ & $7.68 \mathrm{a}$ & $7.98 \mathrm{a}$ \\
\hline \multirow{3}{*}{$\begin{array}{c}\text { Siam } \\
\text { Kintamani }\end{array}$} & Suhu $15^{\circ} \mathrm{C}$ & -0.52 & 2.95 & $4.82 \mathrm{~b}$ & $5.52 \mathrm{~b}$ & $6.22 \mathrm{~b}$ \\
\hline & Suhu $20{ }^{\circ} \mathrm{C}$ & -0.40 & 2.96 & $5.19 \mathrm{~b}$ & $6.57 \mathrm{~b}$ & $6.90 \mathrm{~b}$ \\
\hline & Suhu Ruang $\left( \pm 30^{\circ} \mathrm{C}\right)$ & -0.46 & - & - & - & - \\
\hline
\end{tabular}

Keterangan: Angka rataan yang diikuti huruf yang sama pada kolom yang sama tidak berbeda nyata berdasarkan Uji lanjut Duncan pada taraf $\alpha=5 \%$. (-) adalah buah busuk. CCI= 1000.a/L.b.

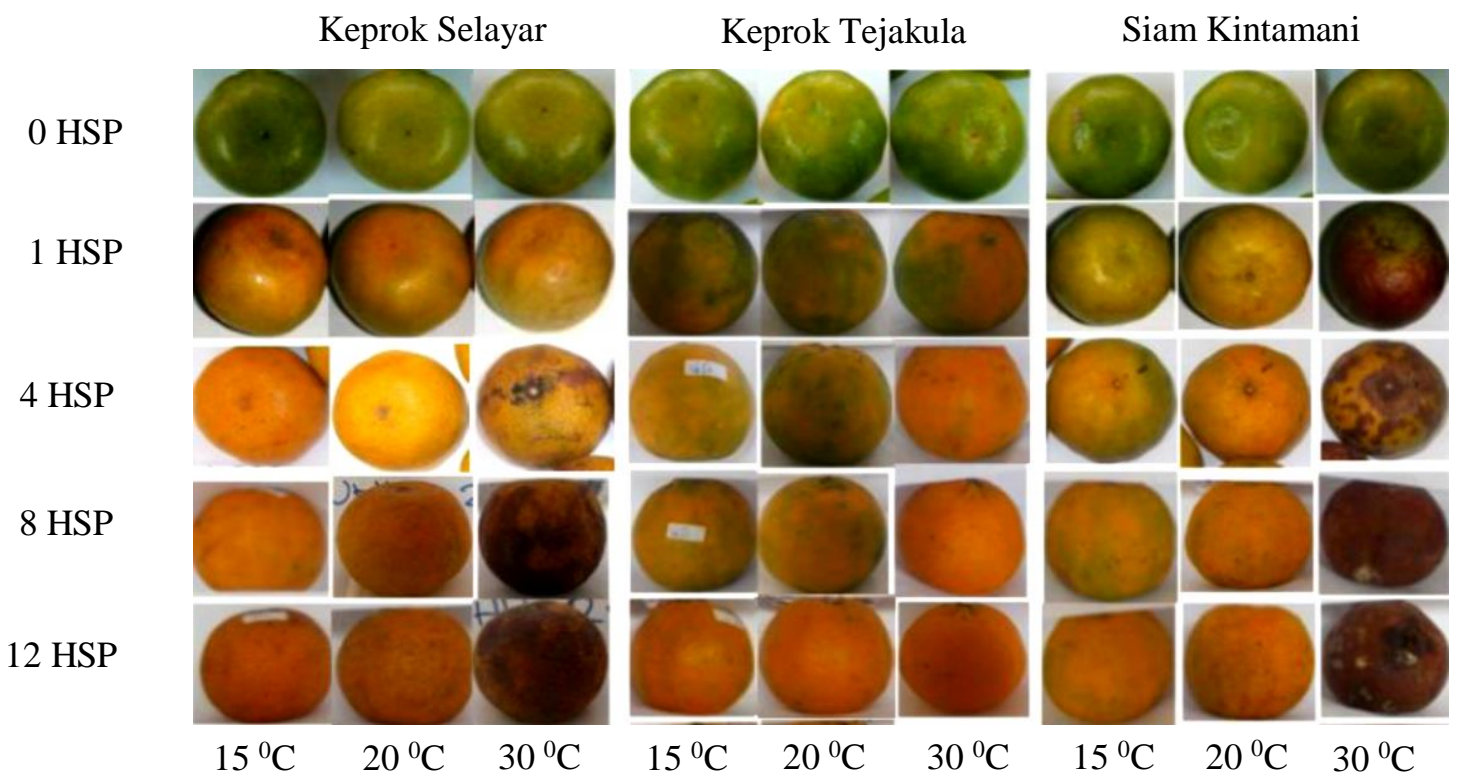

Gambar 2. Perubahan warna kulit buah jeruk Keprok Selayar, Keprok Tejakula dan Siam Kintamani pada 0 HSP (hari setelah perlakuan) sampai dengan 12 HSP.

\section{Pengaruh Degreening terhadap Nilai Hue}

Kulit buah jeruk berwarna jingga ditunjukkan dengan nilai hue $\leq 71.5$. hue $\left({ }^{\circ}\right.$ hue $)$ merupakan hasil konversi dari nilai a dan $\mathrm{b}$ dan menjadi parameter penting dalam metode pengukuran jeruk. Jeruk Keprok Selayar dengan degreening suhu $15{ }^{\circ} \mathrm{C}$ menunjukkan penurunan nilai hue paling tajam, dengan nilai 69.24 pada hari ke-4. Pada jeruk Siam Kintamani yang diberikan perlakuan degreening suhu $15{ }^{\circ} \mathrm{C}$ dan $20{ }^{0} \mathrm{C}$ dapat membentuk warna jingga kekuningan pada hari ke-16 (69.34) dan hari ke-12 (71.55) ditunjukkan pada Gambar 3.

Jeruk Keprok Selayar dari dataran tinggi yang diberikan perlakuan degreening membentuk warna jingga lebih cepat. Hal tersebut sejalan dengan pernyataan Iglesias et al. (2007) menyatakan bahwa suhu dingin berperan penting dalam proses perubahan kulit buah jeruk menjadi jingga. Menurut Jomori et al. (2010) dan Sdiri et al. (2010) suhu selama pertumbuhan buah sangat mempengaruhi perubahan warna kulit buah jeruk. 


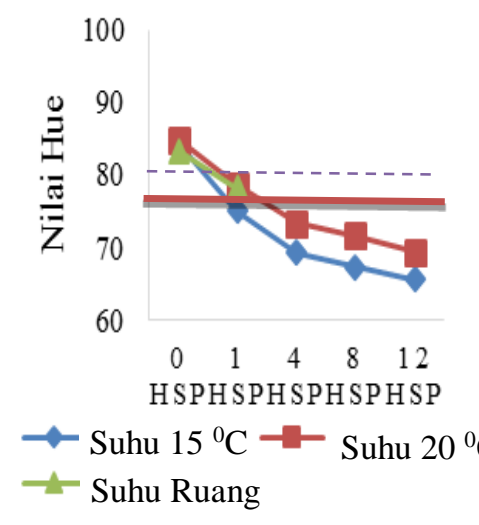

(a)

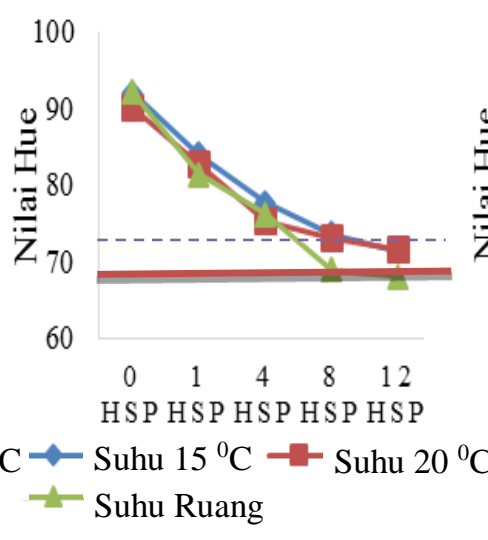

(b)

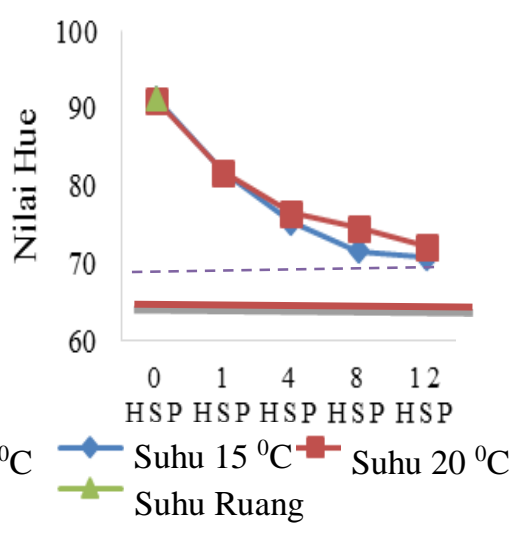

(c)

Gambar 3. Perubahan nilai hue (a) Keprok Selayar, (b) Keprok Tejakula, dan (c) Siam Kintamani pada beberapa suhu degreening

\section{Analisis HPLC B-cryptoxanthin dan Penentuan Kadar Klorofil}

Jeruk Keprok Selayar dan Keprok Tejakula memiliki kandungan $\beta$-cryptoxanthin yang berbeda, hal tersebut disebabkan karena kedua varietas jeruk tersebut ditanam pada daerah dengan ketinggian yang berbeda. Pada Gambar 4 menunjukkan bahwa kandungan $\beta$ cryptoxanthin pada semua varietas dengan perlakuan degreening lebih besar dibandingkan dengan tanpa degreening. Jeruk Keprok Selayar dataran tinggi menunjukkan kandungan $\beta$-cryptoxanthin lebih tinggi dibandingkan dengan Keprok Tejakula dan Siam Kintamani.

Perbedaan ketinggian elevasi jeruk selama pertumbuhan juga mempengaruhi kadar $\beta$-cryptoxanthin. Pada jeruk dataran tinggi dengan perlakuan degreening menunjukkan kadar $\beta$-cryptoxanthin tiga kali lipat lebih tinggi dibandingkan jeruk yang ditanam di dataran rendah. Hal tersebut karena di dataran tinggi suhu selama pertumbuhan buah lebih rendah dibandingkan di dataran rendah. Suhu rendah dapat mengaktifkan gen yang dapat mengakumulasi pigmen $\beta$-citraurin. $\beta$ Citraurin pada tingkat lebih rendah yaitu $\beta$ apo-8'-carotenal, menjadi pigmen utama pada jeruk yang memberikan warna kemerahan cerah serta memberikan kontribusi signifikan dalam karakteristik warna jingga cerah pada jeruk (Oberhoslter et al., 2001; Rios et al., 2010; Carmona et al., 2012).
Nilai kandungan $\beta$-cryptoxanthin pada kulit jeruk Keprok Selayar hari ke-8 HSP sebesar 37.70 ug $\mathrm{g} \mathrm{BS}^{-1}(\mathrm{BS}=$ bobot segar), dan dengan perlakuan degreening pada suhu $15^{\circ} \mathrm{C}$ sebesar 93.07 ug $\mathrm{g} \mathrm{BS}^{-1}$. Nilai kandungan $\beta$ cryptoxanthin pada kulit jeruk Keprok Tejakula tanpa degreening sebesar 17.48 ug $\mathrm{g} \mathrm{BS}^{-1}$, dan degreening suhu $15^{\circ} \mathrm{C}$ menunjukkan nilai lebih tinggi yaitu sebesar 34.40 ug $\mathrm{g} \mathrm{BS}^{-1}$. Hal tersebut terjadi karena peningkatan akumulasi $\beta$-cryptoxanthin, dengan peningkatan akumulasi $\beta$-cryptoxanthin diduga $\beta$-citraurin juga mengalami peningkatan karena $\beta$-cryptoxanthin adalah salah satu pembentuk $\beta$-citraurin.

Kandungan total klorofil pada semua jeruk dengan degreening mengalami penurunan yang tajam, dan kandungan $\beta$-cryptoxanthin lebih tinggi pada semua varietas jeruk dengan degreening dibandingkan tanpa degreening (Gambar 5).

Pigmen dominan pada kulit buah yang belum masak ataupun telah matang yang berwarna hijau ialah klorofil (Rodrigo et al., 2013). Degreening menggunakan etilen digunakan untuk mempercepat perubahan warna pada buah jeruk dari hijau menjadi jingga (Peng et al., 2013). Nilai kandungan total klorofil terendah pada jeruk selayar pada perlakuan degreening pada suhu $15{ }^{0} \mathrm{C}$, sedangkan jeruk Keprok Tejakula dan Siam Kintamani pada suhu $20{ }^{\circ} \mathrm{C}$. 

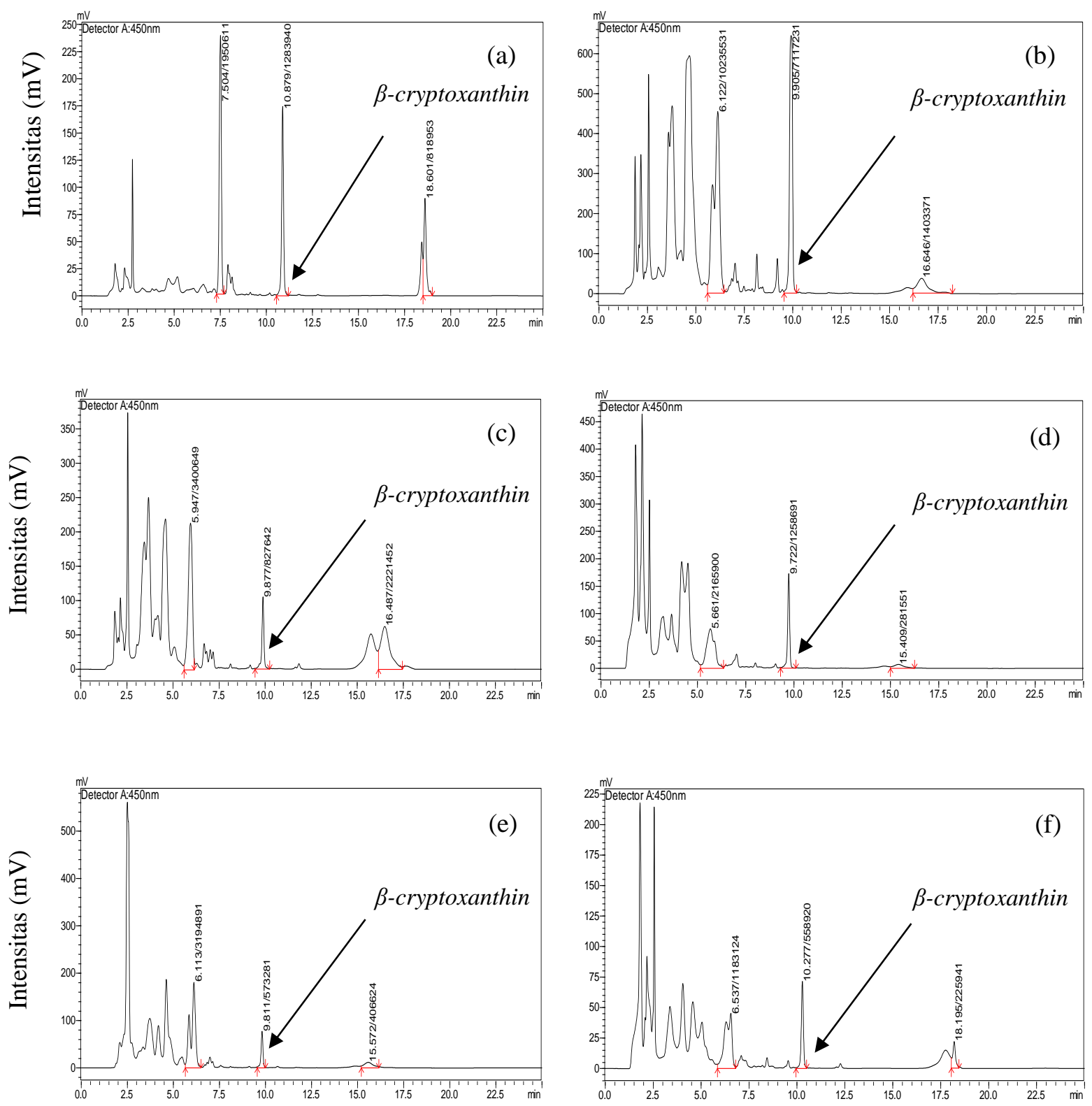

Waktu retensi (menit)

Waktu retensi (menit)

Gambar 4. Analisis HPLC, identifikasi pigmen $\beta$-cryptoxanthin, pada kulit jeruk Keprok Selayar: tanpa degreening (8 HSP) (a), Keprok Selayar dengan degreening (8 HSP) (b), Keprok Tejakula: tanpa degreening (12 HSP) (c), Keprok Tejakula dengan degreening (12 HSP) (d), Siam Kintamani; tanpa degreening (12 HSP) (e), dan Siam Kintamani dengan degreening (12 HSP) (f) 


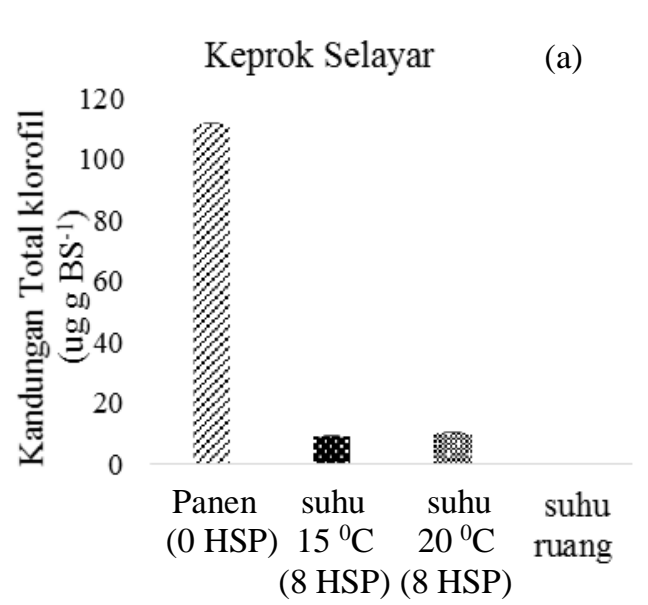

Siam Kintamani

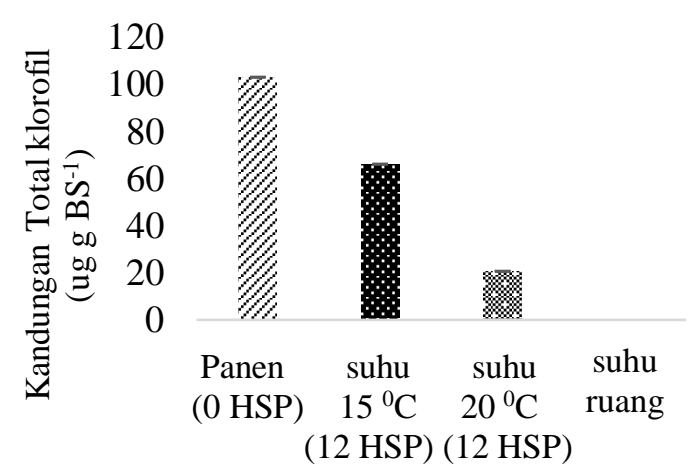

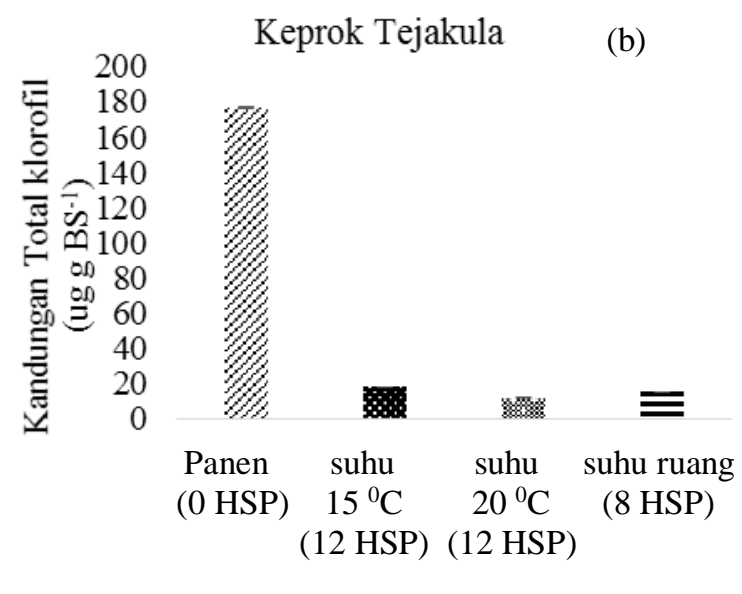

B-Cryptoxanthin

(d)

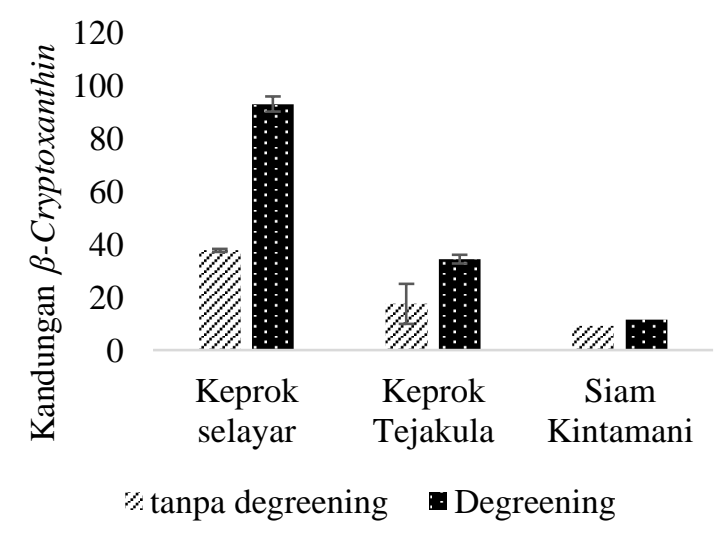

Gambar 5. Perubahan total klorofil (a) Keprok Selayar, (b) Keprok Tejakula, (c) Siam Kintamani, dan kandungan $\beta$-cryptoxanthin $15^{\circ} \mathrm{C}$ (d) pada beberapa suhu degreening.

Pengaruh Degreening terhadap Padatan Terlarut Total (PTT) dan Total Asam Tertitrasi (TAT)

Ukuran untuk mengetahui tingkat kemanisan buah jeruk dinyatakan dalam kandungan padatan terlarut total (PTT). Berdasarkan jenis jeruk dan perlakuan suhu degreening saat pengamatan akhir tidak berpengaruh pada PTT dan total asam tertitrasi (Tabel 2).

Pada akhir penyimpanan yaitu hari ke12 , jeruk keprok tejakula menunjukkan nilai PTT yaitu 8.51 dan pada jeruk keprok selayar yaitu 9.72. Hal tersebut didukung oleh pernyataan Ladaniya (2008), standar kematangan untuk jeruk tropis yang memiliki warna hijau saat panen dengan kriteria masak fisiologis memiliki nilai PTT berkisar antara 9-10.

Penelitian ini menunjukkan bahwa degreening tidak merubah kualitas internal buah jeruk, perbedaan PTT tersebut disebabkan karena berbeda-beda varietas jeruk yang dipakai untuk penelitian, sedangkan suhu degreening tidak menyebabkan perbedaan nyata. Jeruk termasuk kedalam buah non klimakterik, tingkat kematangannya tidak dapat dipacu sehingga cara pemanenan buah jeruk harus dalam kondisi matang fisiologis. Hal tersebut sejalan dengan penelitian Hasimi et al. (2016) bahwa degreening tidak memberikan pengaruh nyata terhadap kualitas internal buah jeruk siam Banyuwangi. Menurut Ladaniya (2008) bahwa sifat jeruk yang non-klimakterik tidak memungkinkan terjadi peningkatan pada rasa buah jeruk setelah dipetik dari pohonnya. Hal ini juga didukung oleh penelitian Mayuoni et al. (2011), bahwa degreening dengan etilen tidak mempengaruhi padatan terlarut total (PTT), vitamin C dan flavonoid total pada buah jeruk sehingga tidak menurunkan kualitas internal buah. 
Tabel 2. Pengaruh suhu degreening dan varietas jeruk terhadap padatan terlarut total (PTT), total asam tertitrasi (TAT) dan kekerasan buah

\begin{tabular}{lcccc}
\hline \multirow{2}{*}{ Perlakuan } & PTT $\left({ }^{\circ} \mathrm{brix}\right)$ & \multicolumn{3}{c}{ TAT $(\mathrm{mg} / 100 \mathrm{~g})$} \\
\cline { 2 - 5 } & $8 \mathrm{HSP}$ & $12 \mathrm{HSP}$ & $8 \mathrm{HSP}$ & $12 \mathrm{HSP}$ \\
\hline Jenis jeruk & & & & \\
Keprok Selayar & $10.55 \mathrm{a}$ & $9.72 \mathrm{a}$ & $0.53 \mathrm{~b}$ & $0.56 \mathrm{a}$ \\
Keprok Tejakula & $9.19 \mathrm{~b}$ & $8.51 \mathrm{~b}$ & $0.64 \mathrm{a}$ & $0.63 \mathrm{a}$ \\
Siam Kintamani & $9.60 \mathrm{~b}$ & $8.54 \mathrm{~b}$ & $0.68 \mathrm{a}$ & $0.50 \mathrm{a}$ \\
\hline Suhu degreening & & & & \\
$15^{\circ} \mathrm{C}$ & $10.07 \mathrm{a}$ & $9.32 \mathrm{a}$ & $0.67 \mathrm{a}$ & $0.54 \mathrm{a}$ \\
$20^{0} \mathrm{C}$ & $9.82 \mathrm{a}$ & $8.97 \mathrm{a}$ & $0.63 \mathrm{ab}$ & $0.57 \mathrm{a}$ \\
Ruang & $9.42 \mathrm{a}$ & $8.46 \mathrm{a}$ & $0.55 \mathrm{~b}$ & $0.59 \mathrm{a}$ \\
\hline Interaksi & tn & tn & tn & tn \\
\hline
\end{tabular}

Keterangan: Angka rerata yang diikuti huruf yang sama pada kolom yang sama tidak berbeda nyata berdasarkan uji lanjut Duncan pada taraf $\alpha=5 \%$.

\section{KESIMPULAN}

Warna terbaik jeruk Keprok Selayar dan Tejakula diperoleh dengan degreening pada suhu $15{ }^{\circ} \mathrm{C}$, Siam Kintamani diperoleh dengan degreening pada suhu $20{ }^{\circ} \mathrm{C}$. Degreening dapat menurunkan kandungan total klorofil secara tajam, dan terbukti meningkatkan kandungan pigmen $\beta$-cryptoxanthin dalam mempercepat pembentukan warna kulit jeruk keprok menjadi jingga. Kandungan pigmen $\beta$-cryptoxanthin setelah degreening, 3 kali lebih tinggi pada jeruk keprok dataran tinggi dibandingkan dengan dataran rendah.

\section{UCAPAN TERIMAKASIH}

Ucapan terimakasih disampaikan kepada PKHT IPB dan LIPI Cibinong yang telah memfasilitasi penelitian ini dan kementerian riset, teknologi, dan pendidikan tinggi melalui hibah PDD dengan nomor kontrak 0432/ $\mathrm{K} 3 / \mathrm{KM} / 2017$ dengan judul studi pembentukan pigmen $\beta$-citraurine dan $\beta$-cryptoxanthin pada buah jeruk dengan degreening dan Kementerian Pertanian RI dengan nomor kontrak 714/LB.620/1.1/2/2013 diketuai oleh Prof. Dr. Ir. Roedhy Poerwanto, MSc. yang telah membantu mendanai penelitian ini.

\section{DAFTAR PUSTAKA}

Andarwulan, N., F. Kusnandar, D. Herawati. 2011. Analisis Pangan. Dian Rakyat. Jakarta.
Arzam, T.S., I.H. Sumiasih, R. Poerwanto, Y.A. Purwanto. 2015. Precooling dan konsentrasi etilen dalam degreening untuk membentuk warna orange kulit buah jeruk siam. J. Hort. 25(3): 257-265.

Carmona, L., L. Zacarías, M.J. Rodrigo. 2012. Stimulation of coloration and carotenoid biosynthesis during postharvest storage of 'Navelina' orange fruit at $12{ }^{\circ} \mathrm{C}$. Postharvest Biology and Technology. 74: 108-117.

[Deptan] Departemen Pertanian. 2015. Outlook Jeruk. Pusat Data dan Sistem Informasi Pertanian Kementerian Pertanian.

Fanciullino, A.L., M. Cercos, C.D. Mayer, Y. Froelicher, M. Talon. P. Ollitrault, R. Morillon. 2008. Changes in carotenoid content and biosintesis gene expression in juice sacs of four orange varities (Citrus sinensis) differing fruit color. J. Agricultural of Food Chemistry. 54: 4397-4406.

Hasimi, N.R., R. Poerwanto, K. Suketi. 2016. Degreening buah jeruk siam (Citrus nobilis) pada beberapa konsentrasi dan durasi pemaparan etilen. J. Hort. Indonesia. 7(2): 111-120.

Iglesias, J.D., M. Cercós, J.M. ColmeneroFlores, M.A. Naranjo, G. Ríos, E. Carrera, O. Ruiz-Rivero, I. Liso, R. Morillon, F.R. Tadeo, M. Talón. 2007. Physiology of citrus fruiting. Brazilian Journal of Plant Physiology. 19: 333-362. 
Jiménez-Cuesta, M.J., J. Cuquerella, J.M. Martínez-Jávega. 1981. Determination of a color index for citrus fruit degreening. In Proc. of the International Society of Citriculture. 2: 750-753.

Jomori, M.L. L., Sestari, F.A.M. Terra, D.G. Chiou, R.A. Klauge. 2010. Degreening of 'Murcott' tangor with ethapon treatments. Proc. IV International Postharvest Symposium. Acta Hort. 877.

Ladaniya, M.S. 2008. Citrus Fruit: Biology, Technology and Evaluation. San Diego CA. Elsevier Academic Press.

Kato, M., Y. Ikoma, H. Matsumoto, M. Sugiura, H. Hyodo, M. Yano. 2004. Accumulation of carotenoids and expression of carotenoid biosynthetic genes during maturation in citrus fruit. Plant Physiol. 134(2): 824-37.

Kato, M., H. Matsumoto, Y. Ikoma, Y.H. Okuda, M. Yano. 2006. The role of carotenoid cleavage dioxygenase in the regulation of carotenoid profiles during maturation in citrus fruit. J. Exp. Bot. Japan. 57(10): 2153-2164.

Karthik, J. Joseph, Karrupiah, J.K. Burns. 2010. Differential ethylene sensitivity during abscission and degreening in citrus. University of Florida.

Ma, G., L. Zhang, A. Matsuta, K. Matsutani, K. Yamawaki, M. Yahata, A. Wahyudi, R. Motohashi, M. Kato. 2013. Enzymatic formation of $\beta$-citraurin from $\beta$ cryptoxanthin and zeaxanthin by carotenoid cleavage dioxygenase 4 in the flavedo of citrus fruit. American Society of Plant Biologists. 682-695.

Manera, J., J.M. Brotons, A. Conesa, I. Porras. 2012. Relationship between air temperature and degreening of lemon (Citrus lemon L. Burm. F) peel color during maturation. Australian Journal of Crop Science. 6(6): 1051-1058.

Martinez-Javega, J.M., A. Monterde, P. Navarro, A. Salvador. 2008. Respons of new clementines to degreening treatment. Proc. Int. Soc. Citriculture. 11: 1342-1346.

Nafisah, S.N. 2013. Sikap dan persepsi konsumen terhadap jeruk lokal dan jeruk impor di pasar modern Kota Bogor. Skripsi. Institut Pertanian Bogor. Bogor. 70 Hal.

Oberholster, R., K. Cowan, P. Molnar, G. Toth. 2001. Biochemical basis of color as an aesthetic quality in Citrus sinensis. J. Agric. Food Chem. 49: 303-307.

Peng, G., X.L. Xie, Q. Jiang, S. Song, C.J. Xu. 2013. Chlorophyll $\mathrm{a} / \mathrm{b}$ binding protein plays a key role in natural and ethyleneinduced degreening of ponkan (Citrus reticulate Blanco). J. Sci. Hortic. 160: 37-43.

Ríos, G., M.A. Naranjo, M. Rodrigo, E. Alós, L. Zacarías, M. Cercós, M. Talón. 2010. Identification of a GCC transcription factor responding to fruit colour change events in citrus through the transcriptomic analyses of two mutants. BMC Plant Biology. 10: 276.

Rodrigo, M.J., M. Alquezar, E. Alos, V. Medina, L. Carmona, M. Bruno. 2013. A Novel carotenoid cleavatage in the biosynthesis of citrus fuit specific apocarotenoid pigments. Experimental Botany. 64: 4461-4478.

Sdiri, S., P. Navarro, A. Monterde, J. Benabda, A. Salvador. 2012. New degreening treatments to improve the quality of citrus fruit combining different periods with and without ethylene exposure. J Postharvest Biol and Technol. 63: 25-32.

Shanti, S.I. 2007. Analisis keputusan konsumen dalam mengkonsumsi jeruk lokal dan jeruk impor di ritel modern (kasus konsumen Giant Botani Square Bogor). Skripsi. Institut Pertanian Bogor. Bogor

Sims, D.A., J.A. Gamon. 2002. Relationship between leaf pigment content and spectral reflectance across a wide range of species, leaf structures and development stages. J. Remote Sensing Envir. 81: 337-354. 
Zhou, Y.J., C.D. Sun, L.L. Zhang, X. Dai, C.J. $\mathrm{Xu}, \quad$ K.S. Chen. 2010. Preferential accumulation of orange-colored carotenoids in Ponkan (Citrus reticulata) fruit peel following postharvest application of ethylene or ethephon. J. Scientia Horticulturae. 126: 229-235. 